\title{
REPORT ON THE 4th WORLD CONFERENCE ON EARTHQUAKE ENGINEERING
}

Three hundred and eighty participants from 29 countries attended the 4 W.C.E.E. held in Santiago, Chile between January 13th and 18th, 1969. One hundred and twenty Chileans registered; the next largest delegations being of ninety-one from the U.S.A. and forty from Japan.

New Zealand had five representatives, G. Cooper and C. M. Strachan from Wellington, $R$. Shepherd and $W$. R. Walpole from Christchurch and J. Healy, N.Z. Government Vulcanologist at present working on a geothermal project in northern chile. Of the three hundred and sixty papers offered, one hundred and fifty were accepted for presentation at the conference; the first four New Zealand representatives listed above each introduced one paper.

Mr C. W. O. Turner of Wellington, Vice-President of the International Association for Earthquake Engineering had the misfortune to experience a motor accident shortly before his planned departure for Chile and consequently was compelled to cancel his arrangements to attend the conference.

Feature sessions included reports of recent major earthquakes particularly those occurring in 1967 at Adapazari in Turkey and Caracas in Venezuela. Unfortunately no arrangements had been made to report on the Inangahua earthquake.

There were twelve technical sessions arranged under the following headings: Seismicity and Simulated Earthquakes, Vibration Tests of Structures, Ground Motion and Instruments, Behaviour of Structural Elements. Elastic Response of Structures, Large Buildings and Structural Details, Inelastic Seismic Response, Design of other Structures, Soils and Soil structures, Foundations and Soil Structure Interaction, Design Criteria and Research, and Small Buildings Criteria and Research.

* Reader in Civil Engineering, University of Canterbury, Christchurch. 
As in previous conferences, a large proportion of the papers dealt with the seismic behaviour of structures or structural components although on this occasion a significant number of papers considered special structures, such as dams, and papers on underground pipe lines, suspension bridges and nuclear power plants were presented.

It was evident that since the last world conference significant progress has been made in the inelastic seismic response prediction field but the group of papers dealing with soil-structure interaction was somewhat disappointing.

On this occasion a group of papers centered attention on the seismic probability and risk problem but little new was offered on the subjects of earthquake measurement techniques and seismic loading simulation methods. The particular problems of pre-stressed concrete and masonry earthquake resistant design received regrettably sparse attention.

It is anticipated that the four volumes of conference proceedings, complete with discussions, will be available later this year from the 4WCEE Technical secretary, P.O. Box 2777, Santiago, Chile, with whom orders should be placed. (A list of papers presented at the Conference follows this report.)

The following officers and Directors were elected for the next four years:-

$\begin{array}{ll}\text { President: } & \text { G. W. Housner, U.S.A. } \\ \text { Executive Vice-President: R. Flores, Chile. } \\ \text { Secretary-General: } & \text { J. K. Minami, Japan. } \\ \text { Directors: } & \text { O. A. Glogau, New Zealand. } \\ \text { N. N. Ambraseys, Great Britain. } & \text { A. Arias, Chile. } \\ & \text { F. J. Borges, Portugal. } \\ \text { L. E. Esteva, Mexico. } \\ \text { J. Krishna, India. } \\ \text { S. Okamoto, Japan. } \\ \text { S. Poliakov, U.S.S.R. } \\ \text { K. Steinbrugge, U.S.A. }\end{array}$

Invitations to hold the next conference in 1973 were received from Italy. India and Turkey, but the actual venue will be decided by postal ballot of the Directors.

In his closing address professor Housner drew attention to the increasing importance of Earthquake Engineering arising from the increase in the world's population. He stressed the need to provide optimum economic protection by means of seismic design and 
emphasised that, consistent with the expectation that some damage will be sustained in severe earthquakes, we need to know more about the behaviour beyond the elastic limit; specifically how close to collapse a structure moves as well as how far it is from yield when in the damage zone.

Attendance at the 4 W.C.E.E. proved to be both stimulating and rewarding. It provided an ideal opportunity to exchange information on recent progress and unsolved problems. The proceedings will contain reference material of value to all those engaged in earthquake engineering activity. 
SESSION A 1.

TITLE

Engineerine Estimates of Ground Shaking and Maximum Earthquake Magnitude.

Seismic Risk Studies in the United States.

Earthquake and Reservoir Loadings.

Statistical Inference of the Future Ear thquake Ground Motion.

Earthquake Probability

The Major Influences on Seismic Risk

A Physically Based Model to Simulate

Strong Earthquake Record on Firm Grounds

Significance of Nonstationarity of Earthquake Motions.

Nondeterministic Analysis of Nonlinear Structures Subjected to Earthquake Excitations.

Structural Responses to Nonstationary Random Excitation.

Simulated Earthquake Motions for Design Purposes.

AUTHOR (S)

G.W. Housner

S.T. Algermissen

J.P. Rothe

Hisao Goto Hiroyuki Kameda

W.G. Milne

A.G. Davenport

Allin Cornell

Erik H. Vanmarcke

Octavio Rascon

C. Allin Cornell

M. Amin

H.T. TS'AO

A.H.S. Ang

Jose Penzien

Shi-chi Liu

Hisao Goto

Kenzo Toki

P.C. Jennings

G.W. Housner

N.C. Tsai

An Earthquake Map of chile.

Cinna Lomnitz

Seismicity Prediction: A Bayesian Approach.

Response of Linear Systems to Certain

Transient Disturbances.

L. Esteva Jorge Elourdy
SESSION A 2 .

TITLE

Analysis of Strong Motion

Accelerograph Records.

On the Earthquake Motions for

Aseismic Designing.

Characteristics of Earthquake Motion

Seismic Observation of Rigid Structure

on Various Soils and Its Review.

Influence of Geometry and Material Properties

on the Seismic Response of Soil Deposits.

Experimental Study on the Vibrational Characteristics of Ground.

Control of Train Operation on the New Tokaido Line on the Occasion of Earthquake.

Field Investigation of the Influence of Site Conditions on Ground and Structural Response.

The Intensity of Ground Motion of the Skopje 1963 Earthquake.

Strong Motion Records and Acceleration.

Emilio Rosenblueth
Studies on the Spectra of Ground Vibrations Caused by Nearby Earthquakes.

Scale of Seismic Intensity .

Maximum Intensity of Ground Movements Caused by Faulting.
D.E. Hudson N.C. Nigam M.D. Trifunac

Kiyoshi Kanai

C. Tamura

T. Mizukoski

- T. Ono

Kinji Akino Tokinaru Ota

.M. Idriss

. Dezfulian

S. Yoshikawa

Japanese Nat:Railway Dr. Tatsuo Nishiki Masao Nonogaki

s. Cherry

Apostol Poceski

William K. Cloud Virgilio Perez

v.v. Shteinberg

S.v. Medvedev

N.N. Ambraseys 
SESSION A 3.

TITLE

AUTHOR (S)

Dynamic Analysis of Tall Buildings

Founded in Deep Fill Materials.

Brick Masonry Effect in Vibrations

Dynamic Elastic Analysis in the Design

of Typical New Zealand High-Rise Buildings.

Structural Dynamics of Cantilever-Type Buildings

Torsion in Symmetrical Buildings

A Study on the Earthquake Response of Space Structures by Digital Computers.

Response Analysis of Framed Structures.

Spectrum Techniques for Tall Buildings.

Earthquake Response of Irregularly

Shaped Buildings.

Earthquake Analysis of Suspension

Bridges

Estimating Natural Frequencies and Modes of Arch Dams with the Theory of Plates

on Elastic Foundation.

Time-History Response of Buildings with Unusual configurations.

H. Sexton

R.J. Feibusch

E.J. Keith

Simon Lamar

Celso por

R:" Shepherd

John A. Blume

Nathan M. Newnark

Kazuhiko Takeyama

Y. Ohchi

Pau1 c. Jennings

Joseph Penzien

S.s. Tezcan

Rudolph Szilard

John A. Blume

Dilip Jhaveri

R.W. Clough
A.J. Carr.
SESSTON A 4.

TITLE

Factors Influencing the Inelastic

Response of Multi-Story Frames Subjected

to Strong Motion Earthquakes.

The Effect of Minimum Cross Bracing on the

Inelastic Response of Multi-story Buildings.

The Effect of Gravity on the collapse of

vielding Structures with Earthquake Excitation.

The Distributed Element Concept of Hysteretic Modeling and Its Application to Transient Problems.

The Ultimate Strength of the Steel structures Subjected to Earthquake.

Torsional Problems in Aseismic Design of High-Rise Buildings.

Elastic and Inelastic Response of Framed Structures During Earthquakes.

.C. Heidebrecht

Robert D. Hanson William F.B. Fan

Raul Husid

W.D. Iwan

Ben Kato

Hiroshi Akiyama

Tadaki Koh

Hiromoto Takase Tsunehisa Tsugaw

N.C. Nigam

Non-Linear Response Analysis of Multi-story

Structures Including Rocking and Swaying

T. Odaka

K. Kinoshita

Torsional Response of Building to strong Earthquake Motions.

Akenori Shibata Junichi Onose Toshio Shiga

The Nonlinear Response of a Multi-Story Prestressed Concrete Structure to Earthquake Excitation.

Maximum Deformations of Certain Nonlinear Systems. A.S. Veletsos

Response Spectra for Elastic and Elastoplastic Systems Subjected to Earthquakes for Short Duration.

To The Final State of Rectangular Frames.

Apostol Poceski

Ryo Tanabashi Tsuneyoshi Nakamura Shunzo Ishida

The Inelastic Response of a Steel Frame.

W.R. Walpole

R. Shepherd 
SESSION A 5.
TITLE

Pore-Water Pressures in Earth Slopes Under Seismic Loading Conditions.

virbratory Compaction of the Soil and Eerthquake in Valdiva, Chile.

Densification of Sand by Vertical Vibrations.

Techniques for Field Measurements of Shear Wave Velocity in Soils.

Mechanism of Earthquake Damage to Embankments and Slopes.

A Study of Earth Dam Models Under Shock Loading..

On Vibration Characteristics of Fill Dams in Earthquakes.

Seismic Analysis of Earth Dams.

Earth Pressure Distribution Behind

Retaining Wall During Earthqua

Vibrations of Earth Dams During Earthquakes.
Earthquake Analysis of Earth Dams.
AUTHOR (S)

H. Bolton Seed Kenneth L. Le

Eugenio Retama

Robert V. Whitma Pedro Ortigosa de Pablo.

c. Martin Duke

A.K. Chopr M. Dibaj

R.W. Clough

. Penzien

Yashimasa Kobayashi

Jap.National Railways.

Jai Krishna

Shamshar. Prakash

S.K. Thakkar

Isao Minami

Hatano $T$.

H. Watanabe

Shamshar Prakash

B.M. Basavanna

I.M. Lavrov

G.A. Lyamzina

S.V. Medvedev
SESSION A 6.

TITLE AUTHOR (S)

Vibration Test of a Structure Supported by Pile Foundation.

Effect of Size and Shape of Foundation on Elastic Coefficients in a Layered Soil Mass.

K. Kubo

Some Special Problems in the Design of

Shamshe Prakash B.M. Basavanna

S.B. Barnes

Dam Foundation Interaction During Earthquakes.

nil K. Chopra P.R. Perumalswan

Dynamic Analysis of a Structure Embedded in an Elastic Stratum.

Some Effects of Substructure and Ad jacent Soil Interaction on the Seismic Response of Building.

A Method of Analysis for the Evaluation of Foundation Structure Interaction.

Soil Structure Interaction of the Elevated Tower and of Concrete Footings.

On Earthquake Response of Elasto Plastic Structure Considering Ground Characteristics.

Hirishi Tajimi

J. Kazuo Minami Joji Sakural

Edward L. Wilso

Kishida

. Matsushita

I. Sakamoto

Minami

Kobor 1

Equivalent Lumped System for Structure Founded Upon Stratum of Soil.

Elastic Soil Structure Interaction.

Robert v. Whitman

J. Khanna

William T. Wheele Earthquake Problems.

Oscillations of Tower Like Structures with Account of Inertia and Elasticity of Solid Medium.
B.G. Korenev

V.A. Illjichjov Deep Foundations. 
SESSION B 1.
TITLE

rthquake Measurements in and Around

a Reinforced Concrete Building.

Study on the Large Scale Displacement

Vibration Tests for the $1 / 25$ Scale of

the 17 Storied Building J.N.R.

Vibration Tests and Test to Failure of a 7 Stories Building Survived a Severe

Observed Earthquake Responses of Bridges.

Vibration Studies of an Arch Dam.

Periods of Buildings of Mendoza City. A Method of Dynamic Model Test of

Use of Resonance Method in Mechanical Modeling of Seismic Effects on Structure

Summarized Report of Dynamic Tests of High-Rised Buildings and Co-operative Plan for Large Scale Vibration Test in Japan.

Dynamic Response of a $90 \mathrm{ft}$ Steel Frame Tower.

Resonance Testing of Multi-store Infilled Frames.

Experimental Results of the Dynamic Deformation of Multi-storey Buildings.

Investigations into Earthquake Resictance

of Large Panel Buildings.
AUTHOR (S)

Y. Osawa

T. Tanaka

Y. Kitagawa

Chikaaki Ueda

Issao Funahashi

Elichi Kuribatas

Toshi Iwasak

Tadahsi Takahashi

Juan S. Carmona Jose Herrera Cano

Shunzo Okamoto

Sh.G. Napatvaridze

P.A. Gutidze

The Group for Dynamic Tests of
High-Rised Buildings

N.N. Nielsen

D.v. Mallick Ph.D.

H. Sand1

G. Serbanexcu

S.V. Polyakov

B.E. Denisov
T. Z ZH. Zhunusov

V.I. Konovodchenk

A.I. Konovodchen
Katsuhiro Kinoshita

SESSION B 2
TITLE

A Research Program on the Earthquak Resistance of Shear Wall Buildings.

A Vibration Test of Large Model Steel

Frame with precast Concrete Panel until

Failure

Low Cycle Fatigue Under Multi-Axial Stress conditions.

On the Aseismicity of Precast Curtain Wal

Damping Capacity of a Model steel Dtructure.

The Coupling of Reinforced Concrete Shear Walls.

Evaluation of Inelastic Seismic Deflections of of Members.

Seismic Behaviour of Reinforced Concrete Frame Structures.

Repeated and Reversed Load Tests on FullScale Steel Frames.

AUTH (S)

A.C. Heidebrecht

W.K. Tso

R. Tamura

. Murakam

N. Tanak

Koji Mizuhata

Seiji Watanabe Shozaburo Shimaguchi

D. Rea

R.W. ciough

Thomas Paulay

Hajime Umemura Hiroyuki Aoyama

Vitelmo Berter Boris Bresler

Lauren Carpenter Le-Wu Lu

Low Cycle Fatigue Fracture Limits of Various Kin of Structural Members Subjected to Alternately Repeated Plastic Bending Under Axial Compression as an Evaluation Basis or Design Criteria for Aseismic Capacity.

Research on Behaviour of Reinforced Concrete Constructions Under the Effect of Seismic Load.

G.w. Kartsivadze The Experimental Study on the Dynamic Behaviour of Reinforced Concrete Frames.

An Experimental Study on the Horizontal

Restoring Forces in Steel Frames Under

Large Vertical Loads.
L.N. Avalishvill

Toshio Shiga

M. Wakabayashi

T. Nonaka Reinforced Concrete Frames Based on the Tests 
TESSION 2 CONT'D Bearing Capacity of Building Material Under Dynamic Repeated Loading.

AUTHOR (S)

S.v. Polyakov

H.V. Bechenev

Ju.I. Kotov

T.V. Potapova
SESSION B 3.

TITLE

Research on the Behaviour of Steel Beam to Column Connections in the Seismic-Resistant Structure.

Reliability of Steel Beam to colum Connections Under Cyclic Loading.

Seismic Behaviour of Steel Beam to

Column Connected Subassemblages.

Variability Analysis of Shear Wall Strectures.

An Approximate Method of Static and Dynamic Analysis of Core-Wall Buildings.

Design of Beam Column Joints for Seismic Resistant Reinforced Concrete Frames.

Seismic Moment Resisting Girder Connecting to Diagonally Aligned Columns.

Antiseismic Design of Multi-Story Steel Frames by Plastic Methods.

The Use of Steel to B.S.968:1962 in the All-Welded Frame of a 19 Storey Building.

Studies on Mechanisms to Decrease Earthquake Forces Applied to Buildings.

Study of the Behaviour of a Hanging Building Under the Effect of an Earthquake.

Absorber System for Earthquake Excitations.
AUTHOR (S)

Takeo Naka Ben Kato Makoto Watabe Masami Nakao

E.P. Popov R.B. Pinkney

Vitelmo Bertero

Jack R. Benjamin

Sukenobu Tani Joji Sakurai Michio Iguchi

w. Gene Corley Norman w. Hanso

Sadaichi Terada Akira Tsuruta

Oscar de Buen

G. Cooper Kiyoo Matsushit Masanori Izumi Carlos Jose Oto Y.P. Gupta 


\section{SESSION B 4}

TITLE

AUTHOR (S)

arthquake Analysis of Reservoir Dam Systems.

Study on the Earthquake Proof Design of Elevated Water Tanks.

Hydrodynamic Pressures Generated by Vertical Earthquake Component.

Seismic Design Criteria for Nuclear Reactor Facilities.

Water Dam Seismic Interaction.

Selection of Design Earthquakes for Nuclear Power Plants.

Hydrodynamic Pressures on Arch Dams During Earthquakes.

Dynamic Stresses of Underground Pipe Line During Earthquakes.

Studies on the Earthquake Resistant Design of Suspension Bridge Tower and Pier System.

Some Long Span Construction in Earthquake Regions and Choice of the Structure on the Basis of Wave Dynamic Theory.

The Effect of Seismic Action on the Dynamic Behaviour of Elevated Water Tanks.

Study of Earthquake Resistance of Boilers and Recommendations for their Design.

Dynamics of Extended-in-Plan Structures in Strong Earthquakes.

Earthquake Response Analysis and Aseismic Design of Cylindrical Tanks.

L. Herrera

H. Sandi
SESSION B 5.

\section{TITLE}

AUTHOR (S)

Anil K. Chopra

E.L. Wilson

Sonobe

T. Nishikawa

A. Victoria Flores

Nathan M. Newmark

William J. Hall

Joseph A. Fische

Bhaskar Nath

B.Tech. Ph.D.

Akio Sakurai

Tadashi Takahashi

Ichiro Konishi

Yoshikazu Yamada

V.A. Bykhovsky

F.V. Bobrov

E.S. Medvedeva

Mihail Ifrim

Christian Bratu

Pavlyk. v.s.

M.F. Barstein

s. Moran Garcia
Seismic Forces and Overturning Moments

in Buildings, Towers and Chimneys.

Seismic Design of Traditional and Pre-fabricate Reinforced Concrete Buildings.

Factors to be Considered in calculating the Input Earthquake Force to Buildings.

Comments on the New Chilean Seismic Code for Buildings.

Criteria for Earthquake Resistance Codes based on Energy Concept Draft Design

code.

Large Size Structures Testing Laboratory and Iteral Loading Test of a Five Storeyed Full size Building Structure.

Earthquake Simulation by Shake Table.

Design and Research Potential of Two Earthquake Simulator Facilities.

Earthquake Engineering Research in the United States.

University of Chile-University of California Program in Earthquake Engineering.

A Probabilistic Model for Seismic Force Design. The University of Illinois Earthquake Simulator.

The Problems of the Reliability and optimalit of the Earthquake Proof Structures.
Steven J. Fenves Nathan M. Newmark

J. Ferry Barges Artur Ravara

K. Matsushita M. Izumi Kuang-Jui Hs
Sakamoto

A. Arias

R. Husid

J. Monge

Cismigiu. Al

Titaru. Em.

Toshihiko Hisada representing Joint Committee on Housing structures.

Enzo Lauletta

J.B. Bouwkamp R.W. Clough

J. Penzien

N. Norby Nielsen William H. Walke

Martin Duke

Augusto Leon R.

Jack R. Benjamin

M.A. Sozen

S. Otani

P. Gulkan

N.N. Nielsen

I.I. Goldenblat N.A. Nicolaenko

A.M. Zharov 
SESSION B 6.

TITLE

Seismic Behaviour and Design of Small Buildings in Chile.

Strengthening of Brick Buildings in Seismic Zones.

Seismic Classification System for old Buildings in New Zealand.

Repairs on Power House and Boilers Support Structure Damaged by 1965 Earthquake.
Ventanas 115 MW Steam Electric Station (Chile)

On One Method of Increasing the Seismic Stability of Brick Buildings.

Restoration of Stone Buildings after Earthquake

Earthquake Engineering as an Aid to Insurability.

Seismic Failure and Repair of an Elevated Water Tank.

\section{SPECIAL PAPERS}

This Session was devoted to the special papers prepare by

RODRIGO FLORES

KIYOSHI MUTO

HENRY J. DEGENKOLB

AUTHOR (S)
Joaquin Monge

Jao Krishna

Brijesh Chandra

C.M. Strachan

Santiago Arias

Victor Arz

A. Churaya

Sh.A. Djabua

Rasskazovsky V.T. Abdurashidov K.S.

Frank Albert

Elias Arze

\begin{tabular}{|l|} 
SPECIAL PAPERS \\
This Session was devoted to the special papers prepared \\
by: \\
RODRIGO FLORES \\
KIYOSHI MUTO \\
HENRY J. DEGENKOLB
\end{tabular}

SESSION J 2 .

TITLE

bservation of Damages of Industrial

Firms in Niigata Earthquake.

Macroseismic Observations From Some Recent Earthquakes.

tructural Engineering Aspects of the 1967 Adapazari Turkey Earthquake.

The Koyna, India, Earthquake.

Lessons From Some Recent Earthquakes

in Latin America.

The Caracas Earthquake of July 29, 1967

The July 29, 1967 Venezuela Earthquak Lessons for the Structural Engineer.

Behaviour of Tall Buildings During the Caracas

Damage Mechanisms and Design Lessons from Caracas.

mplications on Seismic Structural Damage to Design of the Evaluatid

Caracas, Venezuela Earthquake of July 29, 1967.
AUTHOR (S)

Heki Shibata Sumiji. Fujii etc.

N.N. Ambraseys

Rifat Yarar Semih S. Tezcan

G.V. Berg K. A.v. Setlur

Luis Esteva Octavio A. Rascon Alberto Gutierrez

Venezuelean official seismic

Henry J. Degenkol Robert D. Hanson

J. Ferry Borges J. Grases
A. Ravera

R.I. Skinner

M.A. Sozen N.M. Newmark G.W. Housner Diego Ferrer F Lloyd S. Cluf 